\title{
Protein kinase C-delta inactivation inhibits the proliferation and survival of cancer stem cells in culture and in vivo
}

Zhihong Chen ${ }^{1}$, Lora W Forman ${ }^{1}$, Robert M Williams ${ }^{3,4}$ and Douglas V Faller $1,2,5,6,7,8,9^{*}$

\begin{abstract}
Background: A subpopulation of tumor cells with distinct stem-like properties (cancer stem-like cells, CSCs) may be responsible for tumor initiation, invasive growth, and possibly dissemination to distant organ sites. CSCs exhibit a spectrum of biological, biochemical, and molecular features that are consistent with a stem-like phenotype, including growth as non-adherent spheres (clonogenic potential), ability to form a new tumor in xenograft assays, unlimited self-renewal, and the capacity for multipotency and lineage-specific differentiation. PKC $\delta$ is a novel class serine/ threonine kinase of the PKC family, and functions in a number of cellular activities including cell proliferation, survival or apoptosis. PKC $\delta$ has previously been validated as a synthetic lethal target in cancer cells of multiple types with aberrant activation of Ras signaling, using both genetic (shRNA and dominant-negative PKC $\delta$ mutants) and small molecule inhibitors. In contrast, PKC $\delta$ is not required for the proliferation or survival of normal cells, suggesting the potential tumor-specificity of a PKC $\delta$-targeted approach.

Methods: shRNA knockdown was used validate PKC $\delta$ as a target in primary cancer stem cell lines and stem-like cells derived from human tumor cell lines, including breast, pancreatic, prostate and melanoma tumor cells. Novel and potent small molecule PKC $\delta$ inhibitors were employed in assays monitoring apoptosis, proliferation and clonogenic capacity of these cancer stem-like populations. Significant differences among data sets were determined using two-tailed Student's t tests or ANOVA.

Results: We demonstrate that CSC-like populations derived from multiple types of human primary tumors, from human cancer cell lines, and from transformed human cells, require PKC $\delta$ activity and are susceptible to agents which deplete PKC $\delta$ protein or activity. Inhibition of PKC $\delta$ by specific genetic strategies (shRNA) or by novel small molecule inhibitors is growth inhibitory and cytotoxic to multiple types of human CSCs in culture. PKC inhibition efficiently prevents tumor sphere outgrowth from tumor cell cultures, with exposure times as short as six hours. Small-molecule PKC inhibitors also inhibit human CSC growth in vivo in a mouse xenograft model.
\end{abstract}

Conclusions: These findings suggest that the novel PKC isozyme PKC $\delta$ may represent a new molecular target for cancer stem cell populations.

Keywords: Protein Kinase C isozymes, Synthetic lethal interaction, Cancer-initiating cell, Xenograft tumor model

\footnotetext{
* Correspondence: dfaller@bu.edu

${ }^{1}$ Cancer Center, Boston University School of Medicine, K-712C, 72 E. Concord

St., Boston, MA 02118, USA

${ }^{2}$ Department of Medicine, Boston University School of Medicine, K-712C, 72

E. Concord St., Boston, MA 02118, USA

Full list of author information is available at the end of the article
} 


\section{Background}

Much recent data supports the model that a subpopulation of tumor cells with distinct stem-like properties is responsible for tumor initiation, invasive growth, and possibly dissemination to distant organ sites [1-3]. This small subpopulation of cells can divide asymmetrically, producing an identical daughter cell and a more differentiated cell, which, during their subsequent divisions, generate the vast majority of tumor bulk $[4,5]$. A number of names have been used to identify this subpopulation, including "cancer progenitor cells," "cancer stem cell-like cells," and "cancer-initiating cells," but the term "cancer stem cell" (CSC) has received wide acceptance [6].

The first identification of CSCs in solid tumors was made in 2003, when CSCs were identified and isolated from breast cancers using CD44 and CD24 markers [7]. Subsequently, CSCs have been identified in a variety of solid tumors, including glioblastoma [8-10], osteosarcoma [11], chondrosarcoma [12], prostate cancer [13], ovarian cancer [14-18], gastric cancer [19], lung cancer [20,21], colon cancer [22-25], pancreatic cancer [26,27], melanoma [28-30], head and neck cancer [31], and others. CSCs isolated from these different tumor types share some common characteristics including drug resistance, ability to repopulate tumors, and asymmetric division.

CSC exhibit a spectrum of biological, biochemical, and molecular features that are consistent with a stem-like phenotype, including growth as non-adherent spheres (clonogenic potential), superior ability to form a new tumor in in vivo xenograft assays, unlimited self-renewal, and the capacity for multipotency and lineage-specific differentiation [1,32-35]. In particular, CSCs are able to form colonies from a single cell more efficiently than their progeny [36] and to grow as spheres in non-adherent, serum-free culture conditions [37]. Sphere formation in non-adherent cultures has been used as a surrogate in vitro method for detecting CSCs from primary human tumors $[8,20,25,38,39]$. CSC populations also variably exhibit "stem cell-like" markers, such as Nanog, Sox2, aldehyde-dehydrogenase positivity, and telomerase.

Chemoresistance is also considered a hallmark of CSCs $[6,40]$. They characteristically survive chemo- and radiotherapeutic interventions [41] and may thus be responsible for both tumor relapse and metastasis [42]. CSCs are often innately less sensitive to treatment than are the bulk of the tumor cells that they generate [43,44]. These features support the hypothesis that CSCs are the cell subpopulation that is most likely responsible for treatment failure and cancer recurrence [32].

Aberrant activation of Ras signaling, either through mutation of the Ras genes themselves, or through constitutive upstream or downstream signaling, is very common in solid tumors. We have previously identified the protein kinase $\mathrm{C}$ delta (PKC $\delta$ ) isozyme as a Ras synthetic lethal interactor [45-48]. PKC $\delta$ is a serine/threonine kinase of the PKC family, a member of the novel class, and functions in a number of cellular activities including cell proliferation, survival or apoptosis [49]. However, PKC $\delta$ is not required for the proliferation of normal cells, and PKC $\delta$-null animals develop normally and are fertile, suggesting the potential tumor-specificity of a $\mathrm{PKC} \delta$-targeted approach [50]. PKC $\delta$ was validated as a target in cancer cells of multiple types with aberrant activation of Ras signaling, using both genetic (siRNA and dominant-negative PKC $\delta$ ) and small molecule inhibitors [45], by our group $[45,47]$ and later by others [51,52]. "Ras-dependency" in these tumors was not required for these synthetic-lethal cytotoxic effects $[45,46]$. Tumors with aberrant activation of the $\mathrm{PI}_{3} \mathrm{~K}$ pathway or the Raf-MEK-ERK pathway in the setting of wild-type RAS alleles have also been shown to require PKC $\delta$ activity for proliferation or survival $[47,48]$.

In this report, we demonstrate that CSC-like cell populations derived from multiple types of human primary tumors, from human cancer cell lines, and from transformed human cells require PKC $\delta$ activity and are susceptible to agents which deplete $\mathrm{PKC} \delta$ protein or activity.

\section{Methods}

\section{Cell culture}

MCF10A and MCF10C breast cell lines were derived at the Barbara Ann Karmanos Cancer Institute (Detroit, MI) and maintained in DMEM-F/12 medium containing 5\% heatinactivated horse serum, $10 \mu \mathrm{g} / \mathrm{mL}$ insulin, $20 \mathrm{ng} / \mathrm{mL}$ epidermal growth factor, $0.1 \mu \mathrm{g} / \mathrm{mL}$ cholera enterotoxin, and $0.5 \mu \mathrm{g} / \mathrm{mL}$ hydrocortisone [53,54]. Breast cancer cell lines MCF7, Hs587T, and MDA231 were purchased from ATCC, and were propagated in 10\% fetal bovine serum (Invitrogen, Grand Island, NY); Dulbecco's Modification of Earle's Media (Cellgro, Herndon, VA); 2 mM L-Glutamine (Invitrogen); $200 \mathrm{U}$ Penicillin/ml; $200 \mu \mathrm{g}$ Streptomycin/ml (Invitrogen).

Human breast cancer stem cells (BCSC: CD133+, CD44+, SSEA3/4+, Oct4+, Alkaline Phosphatase+, Aldehyde Dehydrogenase+, Telomerase+), pancreatic cancer stem cells (PCSC: $\mathrm{CD}_{4} 4^{+}, \mathrm{CD} 133^{+}$, SSEA3 $/ 4^{+}$, Oct4 ${ }^{+}$, Alkaline Phosphatase $^{+}$, Aldehyde Dehydrogenase ${ }^{+}$, Telomerase $^{+}$, and $\mathrm{Nestin}^{+}$), and prostate cancer stem cells (PrCSC: CD44, $\mathrm{CD} 133^{+}, \mathrm{SSEA} 3 / 4^{+}$, Oct $4^{+}$, alkaline phosphatase ${ }^{+}$, aldehyde dehydrogenase ${ }^{+}$, and telomerase ${ }^{+}$) were purchased from Celprogen (San Pedro, CA), and cultured using specialized media and tissue culture plastic and matrix, to preserve their CSC phenotype, according to the manufacturer's instructions.

\section{Reagents}

Rottlerin was purchased from (EMD Biosciences, San Diego, CA). The PKC $\delta$ inhibitor KAM1 was previously 
described [47]. BJE6-106 was synthesized as described elsewhere [55]. Briefly, 9-(2-(trifluoro- $\lambda^{4}$-boranyl) ethyl)-9H-carbazole, potassium salt (Molander Salt 1), 6bromo-2,2-dimethyl-2H-chromene-8-carbaldehyde, $64.0 \mathrm{mg}$ (0.213 mmol, 1 equiv.), $\mathrm{PdCl} 2(\mathrm{dppf})-\mathrm{CH} 2 \mathrm{Cl} 2$, and anhydrous $\mathrm{Cs}_{2} \mathrm{CO}_{3}$ were combined to form 6-(2- $(9 \mathrm{H}$-carbazol9-yl)ethyl)-2,2-dimethyl-2H-chromene-8-carbaldehyde (BJE6-106).

\section{Tumor sphere formation}

Tumor self-renewing and anchorage-independent spheroids were obtained by culturing breast cancer cells MCF7, Hs587T and MDA231; melanoma cells SBcl2 and FM6; human breast cancer stem cells and pancreatic cancer stem cells in stem cell-selective conditions according to the manufacturer's instructions (StemCell Technologies, Tukwila, WA). Briefly, cancer and cancer stem cells were propagated in 6-well ultra-low adherent plates (Corning) in Complete MammoCult Medium (Human) by adding $50 \mathrm{~mL}$ of MammoCult Proliferation Supplements to $450 \mathrm{~mL}$ of MammoCult Basal Medium (StemCell Technologies). The following were added to obtain Complete MammoCult Medium: $4 \mathrm{ug} / \mathrm{mL}$ Heparin (StemCell Technologies), $0.48 \mu \mathrm{g} / \mathrm{mL}$ hydrocortisone (StemCell Technologies), $200 \mathrm{U}$ penicillin/ml; and $200 \mu \mathrm{g}$ streptomycin/ml (Invitrogen).

\section{Flow cytometry}

Cell staining for CD24 or CD44: MCF7 and MCF7 spheres, Hs587T and Hs587T spheres, MDA231 and MDA231 spheres, breast cancer stem cells and breast cancer stem cell spheres were collected and stained or dualstained with Fluorescein isothiocyanate (FITC)-anti-CD24 and (PerCP-Cy)-anti-CD44 (BD Pharmingen, San Diego, $\mathrm{CA})$ monoclonal antibody (mAbs) for $30 \mathrm{~min}$ on ice. The stained cancer cells and sphere populations were analyzed by FACSCAN analysis.

\section{Clonogenic assays}

100,000 cells were seeded on $100 \mathrm{~mm}$ dishes with $10 \mathrm{ml}$ media per dish [47]. On day 4, cells were treated with a PKC $\delta$ inhibitor or vehicle control for either $6,18,24$ or 48 hours. Cells were trypsinized; counted via the trypan blue exclusion method in order to determine the number of live cells in the sample, and 300 live cells were seeded in triplicate onto 6-well plates. Cells were monitored for appropriate colony size and re-fed every three to four days. At Day 15, cells were stained with ethidium bromide [56] and counted using UVP LabWorks software (Waltham, MA).

\section{Cell proliferation assays}

Cell proliferation was assessed using an MTT [3-(4,5-dimethylthiazol-2-yl)-2,5-diphenyltetrazolium bromide] assay
(Roche, Mannheim, Germany). The number of viable cells growing in a single well on a 96-well microtiter plate was estimated by adding $10 \mu \mathrm{l}$ of MTT solution $(5 \mathrm{mg} / \mathrm{ml}$ in phosphate-buffered saline [PBS]). After $4 \mathrm{~h}$ of incubation at $37^{\circ} \mathrm{C}$, the stain was diluted with $100 \mu \mathrm{l}$ of dimethyl sulfoxide. The optical densities were quantified at a test wavelength of $570 \mathrm{~nm}$ and a reference wavelength of $690 \mathrm{~nm}$ on a multiwell spectrophotometer. In some assays, MTS was used as substrate (Promega, Madison, WI), and the absorbance of the product was monitored at $490 \mathrm{~nm}$. Cell enumeration was carried out using a hemocytometer, and viable cells identified by trypan blue exclusion.

\section{PKC kinase activity assays}

Assays were carried out using recombinant PKC $\delta$ or $\mathrm{PKC} \alpha$, (Invitrogen) and the Z-lyte Kinase Assays (Invitrogen) with a "PKC-kinase-specific" peptide substrate. FRET interactions produce a change in fluorescence (ex455/ ex520) upon phosphorylation. The kit was used according to the manufacturer's instructions.

\section{Cytotoxicity assay}

LDH release was assessed by spectrophotometrically measuring the oxidation of $\mathrm{NADH}$ in both the cells and media. Cells were seeded in 24-well plates, and exposed to PKCס inhibitors or vehicle. After different times of exposure, cytotoxicity was quantified by a standard measurement of LDH release with the use of the LDH assay kit (Roche Molecular Biochemicals) according to the manufacturer's protocol. Briefly, total culture medium was cleared by centrifugation. For assay of released LDH, supernatants were collected. To assess total LDH in cells, Triton X-100 was added to vehicle (control) wells to release intracellular LDH. LDH assay reagent was added to lysates or supernatants and incubated for up to $30 \mathrm{~min}$ at room temperature in dark, the reaction was stopped, and the absorbance was measured at $490 \mathrm{~nm}$. The percentage of $\mathrm{LDH}$ release was then calculated as the $\mathrm{LDH}$ in the supernatants as a fraction of the total LDH.

\section{Immunoblot analyses}

Levels of proteins were measured and quantitated in cells as we have previously reported [45]. Harvested cells were disrupted in a buffer containing $20 \mathrm{mM}$ Tris ( $\mathrm{pH} 7.4$ ), $0.5 \% \mathrm{NP}-40$, and $250 \mathrm{mM} \mathrm{NaCl}$ with protease and phosphatase inhibitors. Total protein $(40 \mu \mathrm{g})$ was separated on $10 \%$ SDS-polyacrylamide gels and transferred to nitrocellulose membranes or PVDF membranes. Membranes were blocked overnight and probed with affinity-purified antibodies against: PKC $\delta$ (BD Transduction Labs, San Jose, $\mathrm{CA}$ ), or $\beta$-actin or $\alpha$-tubulin (Sigma Aldrich, St. Louis, MO). Antibodies against human ERK, phospho-ERK1/2 (Thr202/Tyr204), AKT and phospho-AKT (Ser473), JNK and phospho-JNK (Thr183/Tyr185) were purchased from 
Cell Signaling (Danvers, MA). After washing, the blots were incubated with horseradish peroxidase-conjugated secondary antibodies and visualized using the Amersham enhanced chemiluminescence ECL system, and quantitated by digital densitometry.

\section{Down-regulation of PKC by shRNA and lentiviral vectors} shRNA duplexes for PKC $\delta$ (shRNAs) were obtained from Qiagen (Valencia, Ca). The shRNA sequences for targeting PKC $\delta$ and the corresponding scrambled shRNAs used as negative controls were previously described [47]. The lentiviral vectors were previously described [46]. After infection of cells with the vectors, one aliquot was utilized in proliferation assays and a parallel aliquot was subjected to immunoblotting to assay the efficiency of the knockdown.

\section{Xenograft studies}

These studies were performed with the approval of the Institutional Animal Care and Use Committee of Boston University. Breast cancer stem cells $\left(2 \times 10^{5}\right)$ grown from a metastatic tumor were suspended in human breast cancer stem cell complete growth media (Celprogen, San Pedro, CA) and injected subcutaneous into the right flank of female J:NU mice (The Jackson Laboratory, ME) under anesthesia. After palpable tumors developed, the mice were divided into two groups of animals. The control group received daily intraperitoneal injections of vehicle (DMSO) while the treatment group received daily intraperitoneal injections of a PKC $\delta$ inhibitor (rottlerin 5,000 $\mu \mathrm{g} / \mathrm{kg}$ ) for 15 days. The length and width of tumors were measured with a vernier caliper and tumor volumes were calculated. Survival was calculated as the day tumors reached the maximum size allowed by the protocol $(2 \mathrm{~cm}$ diameter $)$.

\section{Statistical analysis}

Experiments were carried out in triplicate for all experimental conditions. Data are shown as mean \pm SD. Where applicable, a two-tailed Student's t test or ANOVA was performed on the means of two sets of sample data and considered significant if $\mathrm{p} \leq 0.05$.

\section{Results}

Inhibition of PKC $\delta$ is growth-inhibitory and cytotoxic in human prostate and pancreatic cancer stem cells

The sensitivity of human cancer stem cell cultures to inhibition of PKC $\delta$ was first examined using shRNA methodology to specifically and selectively knockdown transcripts for this $\mathrm{PKC}$ isozyme and thereby specifically validate $\mathrm{PKC} \delta$ as a target in CSCs. Cell cultures derived from a primary human pancreatic adenocarcinoma (PCSC) and from a primary human prostate adenocarcinoma (PrCSC), isolated by phenotypic markers, were studied. These cells were characterized as "stem-like" by a number of criteria. The PCSC and the PrCSC cultures were $\mathrm{CD}_{4} 4^{+}, \mathrm{CD}_{133^{+}}, \mathrm{Nanog}^{+}$, Sox $2^{+}$, aldehyde dehydrogenase $^{+}$, and telomerase ${ }^{+}$. The PCSC cultures were also Nestin $^{+}$. Both cell types were tumorigenic at $<1000$ cells in xenograft assays in SCID mice, and also formed tumor spheroids at high efficiency. Lentiviral vectors expressing $\mathrm{PKC} \delta$-specific shRNAs (PKC $\delta$-shRNA), which we have previously shown to be specific for the PKC $\delta$ isozyme among all the other PKC isozymes [45-47], were used to deplete PKC $\delta$ levels in the cells. A vector containing a scrambled shRNA (sc-shRNA) served as a control. Specific knockdown of PKC $\delta$ by shRNA was growth-inhibitory in both the human prostate (PrCSC) and pancreatic (PCSC) cancer stem cells, with significant effects observed at early as $24 \mathrm{hr}$ after infection, and progressing up to $72 \mathrm{hr}$ (Figure 1A). The non-targeted lentiviral vector (sc-shRNA) generated modest but reproducible effects on cell growth over time, as we have observed in prior reports [45-47]. Cytotoxic effects of PKC $\delta$ depletion on the PCSC and PrCSC cultures were assessed by quantitating release of cellular LDH. Significant cytotoxicity was elicited by the PKC $\delta$-specific shRNA as early as $24 \mathrm{hr}$ after infection, with LDH release approaching the maximum possible levels by $72 \mathrm{hr}$. The effects of the scrambled shRNA on LDH release did not differ from those of the infection vehicle alone at any time point (Figure 1B). Efficient knockdown of the PKC $\delta$ isozyme was verified by immunoblotting (Figure 1C).

While the specificity of shRNA is essential for validation of a target, small-molecule enzyme inhibitors are more likely than shRNA to translate towards clinical application. We therefore next examined the effects of existing and novel small molecule inhibitors of PKC $\delta$. Rottlerin, a natural product, has been identified as a $\mathrm{PKC} \delta$ inhibitor for many years [47], with an in vitro $\mathrm{IC}_{50}$ of approximately $5 \mu \mathrm{M}$ in our kinase assays (Table 1), in good agreement with the literature $[57,58]$ (although it also exerts inhibitory effects on certain non-PKC kinases at concentrations comparable to the $\mathrm{IC}_{50}$ for PKC [59]). We and others have shown that rottlerin, at the concentrations employed herein, is not cytostatic or cytotoxic to normal primary cells or cell lines, and is well-tolerated when administered orally or intraperitoneally to mice (see also the studies on normal human breast epithelial cells and the in vivo studies later in this report) [45-47]. Exposure of PCSC and PrCSC cultures to rottlerin produced a significant dosedependent inhibition of proliferation as early as $24 \mathrm{hr}$ after exposure (Figure 2A). Similarly, rottlerin induced cytotoxicity in both CSC cultures in a dose-dependent fashion, as assessed by $\mathrm{LDH}$ release (Figure $2 \mathrm{~B}$ ). The duration of

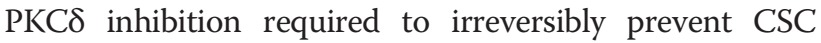
proliferation was next assessed. Exposure to rottlerin efficiently decreased the clonogenic capacity of PCSC. Eighteen hr of exposure to rottlerin, followed by washout, 


\section{A}
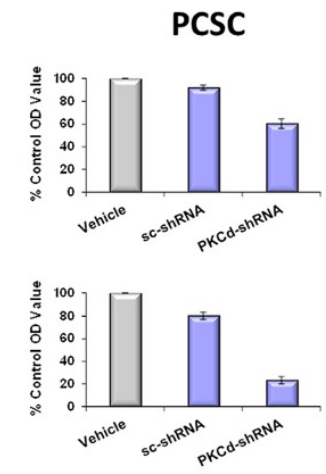

B
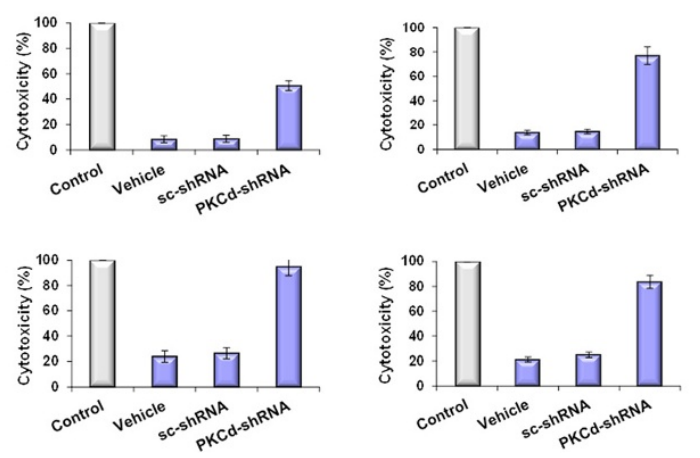

$24 \mathrm{~h}$

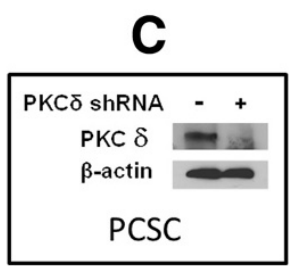

$24 \mathrm{~h}$

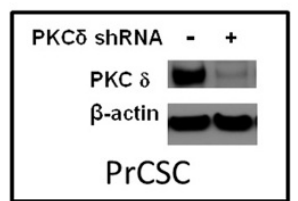

Figure 1 Effects of PKC $\delta$ knockdown by shRNA on proliferation and viability of human pancreatic (PCSC) and prostate (PrCSC) cancer stem cell cultures. (A) PCSC and PrCSC cells were grown to 50\% confluence in 96-well plates and then infected with PKC $\delta$-shRNA-expressing lentivirus vector or a lentiviral vector containing a scrambled shRNA (sc-shRNA). The corresponding equivalent volumes of diluent used for infection served as vehicle controls (Vehicle). 24 and $72 \mathrm{hr}$ after transfection, cell mass was evaluated by MTS assay. Error bars represent SEM. p values for comparison between control (scrambled shRNA) and PKC $\delta$-shRNA effects on cell number reached significance at $24 \mathrm{hr}$ of exposure $(p<0.001)$ for all cell lines, and remained significant at the $72 \mathrm{hr}$ time point. (B) PCSC and PrCSC cells were grown to 50\% confluence in 96-well plates and then infected with PKC - -shRNA or scrambled shRNA (sc-shRNA) expressing lentiviruses. The corresponding equivalent volumes of diluent were used as vehicle controls (Vehicle). After 24 and $72 \mathrm{hr}$ of infection, cell cytotoxicity was evaluated by LDH-release assay. Total maximal LDH release was assigned the arbitrary value of 100\% (Control). Error bars represent SEM. p values for comparison between effects on LDH release for cells infected with scrambled shRNA-expressing vectors compared to PKC $\delta$-shRNA vectors reached significance at $24 \mathrm{hr}$ of exposure $(p<0.01)$ for all cell lines, and remained significant at the $72 \mathrm{hr}$ time point. (C) Immunoblot analysis of PKC protein levels in the same cell lines $72 \mathrm{hr}$ after infection with PKC $\delta$-targeting shRNA expressing lentiviral vectors (+) or scrambled shRNA (-). PKC $\delta$-targeted shRNA vectors efficiently reduced PKC $\delta$ protein expression. Immunoblotting with a $\beta$-actin antibody after stripping the blots served as a loading control.

was sufficient to decrease the clonogenic capacity of PCSC by $40 \%$, and increasing the duration of the exposure to $48 \mathrm{hr}$ reduced the clonogenic potential by more than $90 \%$ (Figure 2C).

As previously reported, we have sought to develop novel $\mathrm{PKC} \delta$-inhibitory molecules with greater specificity for PKC $\delta$ compared to essential PKC isozymes, such as $\mathrm{PKC} \alpha$, using pharmacophore modeling and structure-

Table 1 Comparison of three generations of PKC $\delta$ inhibitors

\begin{tabular}{|c|c|c|c|}
\hline Generation & ${\mathrm{PKC} \delta I C_{50}}$ & $\mathrm{PKCalC}_{50}$ & $\begin{array}{c}\mathrm{PKC} \delta / \mathrm{PKCa} \\
\text { Selectivity ratio }\end{array}$ \\
\hline 1 & $3 \mu \mathrm{M}$ & $75 \mu \mathrm{M}$ & 28-fold \\
\hline 2 & $2 \mu \mathrm{M}$ & $157 \mu \mathrm{M}$ & 56-fold \\
\hline 3 & $0.05 \mu \mathrm{M}$ & $50 \mu \mathrm{M}$ & 1000-fold \\
\hline
\end{tabular}

activity relationships (SAR) [47]. We designed and synthesized a set of analogs based on this strategy. In this $2^{\text {nd }}$ generation of PKC $\delta$ inhibitors, the "head" group (carbazole portion) was made to resemble that of staurosporine, a potent general PKC inhibitor, and other bisindoyl maleimide kinase inhibitors, with two other domains (cinnamate side chain and benzopyran) conserved from the rottlerin scaffold to preserve isozyme specificity. The first such chimeric molecule reported, KAM1 (Figure 2D), was indeed active, like staurosporine, but was also more $\mathrm{PKC} \delta$-specific, and showed potent activity against Ras-mutant human cancer cells in culture and in vivo animal models, while not producing cytotoxicity in nontransformed cell lines [47]. KAM1 induced cytotoxicity as assessed by LDH release in a dose-dependent fashion in both PCSC and PrCSC cultures at concentrations as low as $2.5 \mu \mathrm{M}$ (PCSC) and $5 \mu \mathrm{M}$ (PrCSC) (Figure 2E). 


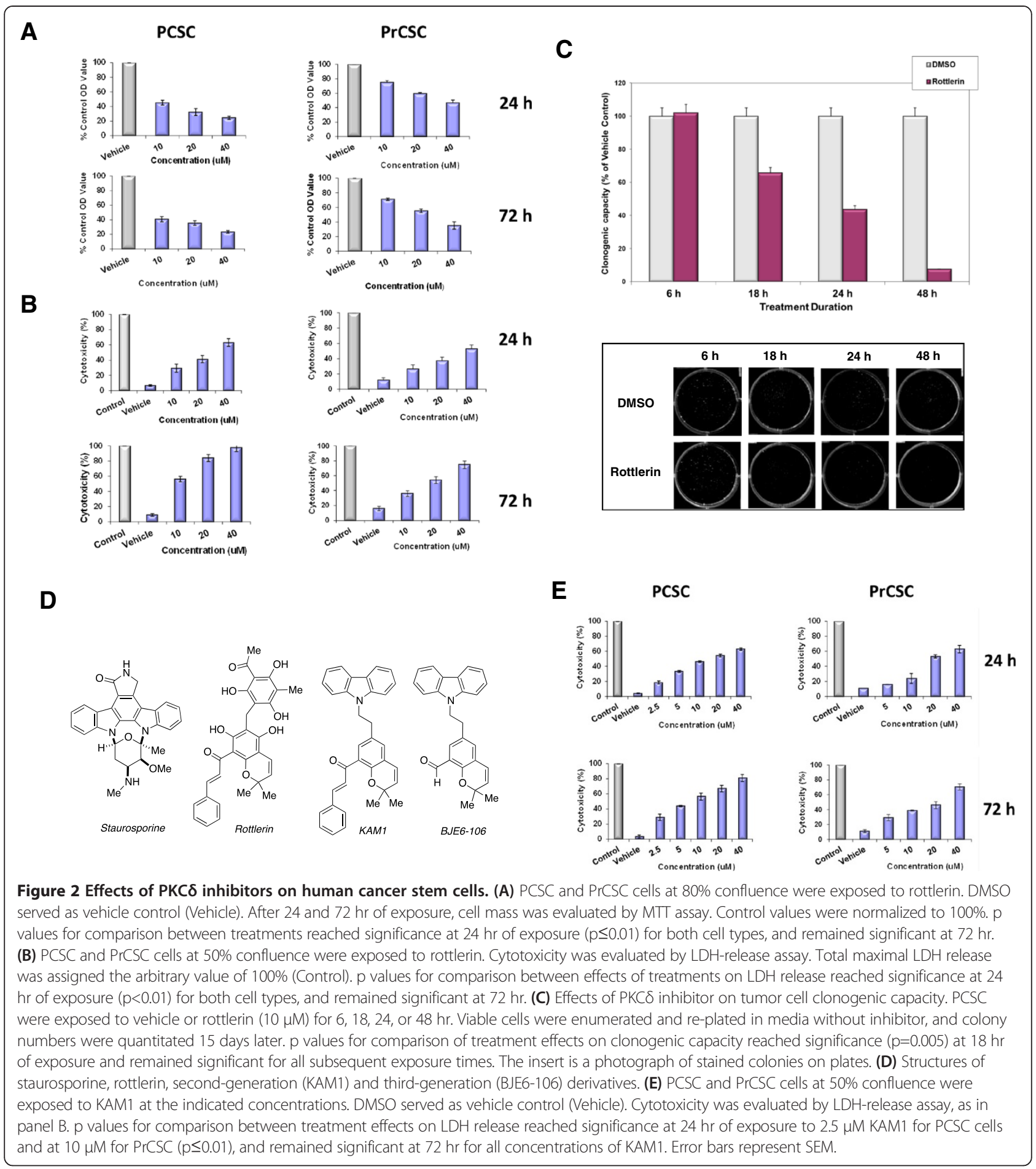

On the basis of SAR analyses of KAM1, we then designed thirty-six new $3^{\text {rd }}$-generation analogs. The synthetic chemistry platform that was used to prepare KAM1 was modified to synthesize these additional analogs, which were then tested for biochemical and cellular activity. The PKC $\delta$-inhibitory activity and isozyme-specificity of this $3^{\text {rd }}$ generation was quantitated in vitro. A number of these $3^{\text {rd }}$ generation analogs demonstrated significant increases in potency and isozyme specificity over rottlerin $\left(1^{\text {st }}\right.$ generation) and KAM1 ( $2^{\text {nd }}$ generation). The new compound selected for study in this report, BJE6-106, is much more potent than rottlerin. BJE6-106 has an (in vitro) PKC $\delta$ $\mathrm{IC}_{50}$ in the range of $0.05 \mu \mathrm{M}$, compared to $3 \mu \mathrm{M}$ for rottlerin (Table 1), is approximately 1000-fold more 
inhibitory against $\mathrm{PKC} \delta$ than $\mathrm{PKC} \alpha$ in vitro, and produces cytotoxic activity against cells with aberrant Ras signaling at $\mathrm{nM}$ concentrations [55].

The activity of the $3^{\text {rd }}$ generation PKC $\delta$ inhibitor BJE6-106 on the growth of PCSC cells in culture was compared to rottlerin. BJE6-106 inhibited the growth of PCSC cultures at concentrations as low as $0.1 \mu \mathrm{M}$, and had an (in culture) $\mathrm{IC}_{50}$ of approximately $0.5 \mu \mathrm{M}$ at $48 \mathrm{hr}$ (Figure 3 ). In contrast, rottlerin produced no significant inhibitory activity at $0.5 \mu \mathrm{M}$, and displayed an $\mathrm{IC}_{50}$ at $48 \mathrm{hr}$ of approximately $3 \mu \mathrm{M}$. LDH release assays also showed greater than 10-fold increases in potency for BJE6-106 compared to rottlerin (data not shown).

\section{Inhibition of PKC $\delta$ prevents tumor sphere formation}

Sphere formation assays, which have been commonly used to identify and purify normal and malignant stem cells, were used to select a "CSC-like population" from established human breast cancer cell lines Hs578T, MDA231 and MCF7. A subpopulation of these cell lines could grow as non-adherent spheres and be continuously propagated in a defined serum-free medium in vitro. Flow cytometry and immunofluorescence analysis indicated that sphere- derived cells from cell lines contained a much larger proportion of cells expressing CD44, a candidate surface marker of breast cancer stem cells, and/or a smaller proportion of cells expressing the non-stem cell marker CD24, compared with adherent cells (Figure 4A). The frequency of spheroid formation relative to input cell number was low for the tumor cell lines $(\leq 2-3 \%)$, as expected. In contrast, spheroid formation from the cultures of primary PCSC or primary breast cancer stem cells (BCSC) was much more efficient (45\% and 53\%, respectively). As expected, the CD24/CD44 profiles of cells in the spheres derived from the primary PCSC and BCSC did not differ from the adherent cells (not shown).

Addition of rottlerin or BJE6-106 to the culture medium very efficiently inhibited the formation of spheroids from all of these cell types (Figure 4B), demonstrating cytostatic or cytotoxic activity on tumor cells having a CSC-like phenotype. Interestingly, the actions of these compounds appeared to be even more potent on the CSC subpopulation in the MCF7 cell line than on the adherent "parental" cells (although different assays are being compared). When the MCF7 adherent population, containing predominantly non-CSC, was exposed
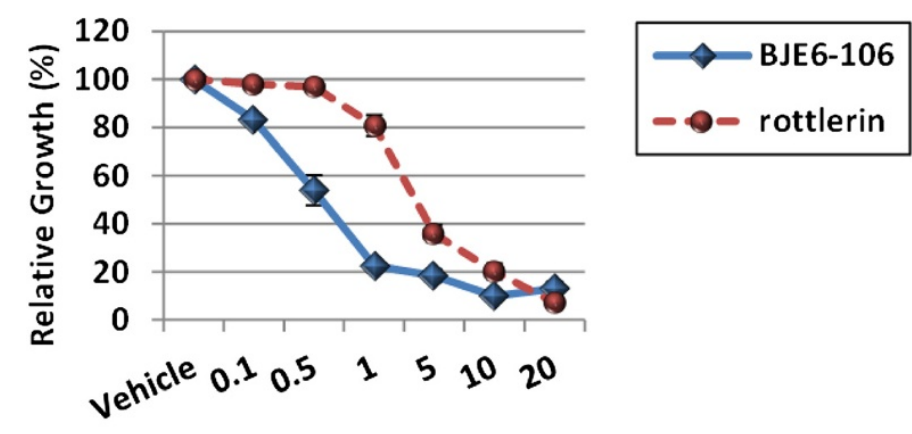

\section{$48 \mathrm{~h}$}

\section{Concentration (uM)}

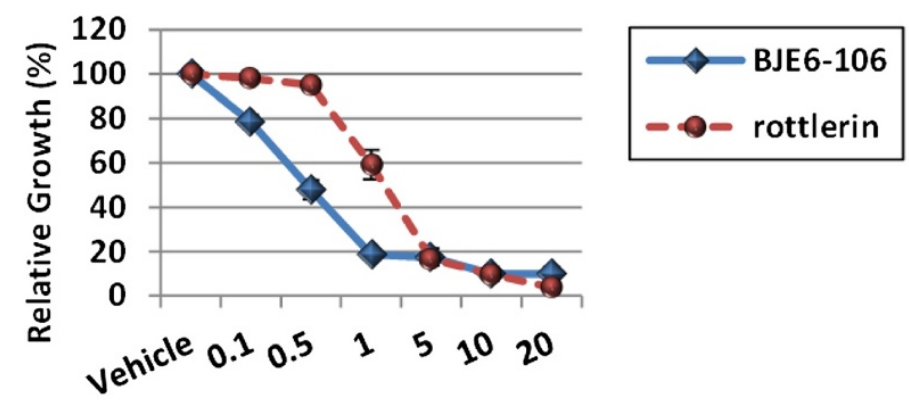

$72 \mathrm{~h}$

\section{Concentration (uM)}

Figure 3 Effects of a $3^{\text {rd }}$ generation small molecule PKC $\delta$ inhibitor on human pancreatic cancer stem cell cultures. PCSC cells were grown to $80 \%$ confluence in 96-well plates and then exposed to BJE6-106 at concentrations ranging from 0.1 to $20 \mu \mathrm{M}$, or to rottlerin at concentrations ranging from 1 to $20 \mu \mathrm{M}$. The corresponding equivalent volume of solvent (DMSO) was used as a vehicle control (Vehicle). After 48 and 72 hr of exposure, cell mass was evaluated by MTT assay. Control values were normalized to 100\%. Error bars represent SEM. p values for comparison between vehicle and rottlerin effects on cell number at $48 \mathrm{hr}$ reached significance at $1 \mu \mathrm{M}$, and for BJE6-106 at $0.1 \mu \mathrm{M}(\mathrm{p} \leq 0.02)$, and remained significant at the $72 \mathrm{hr}$ time point. 


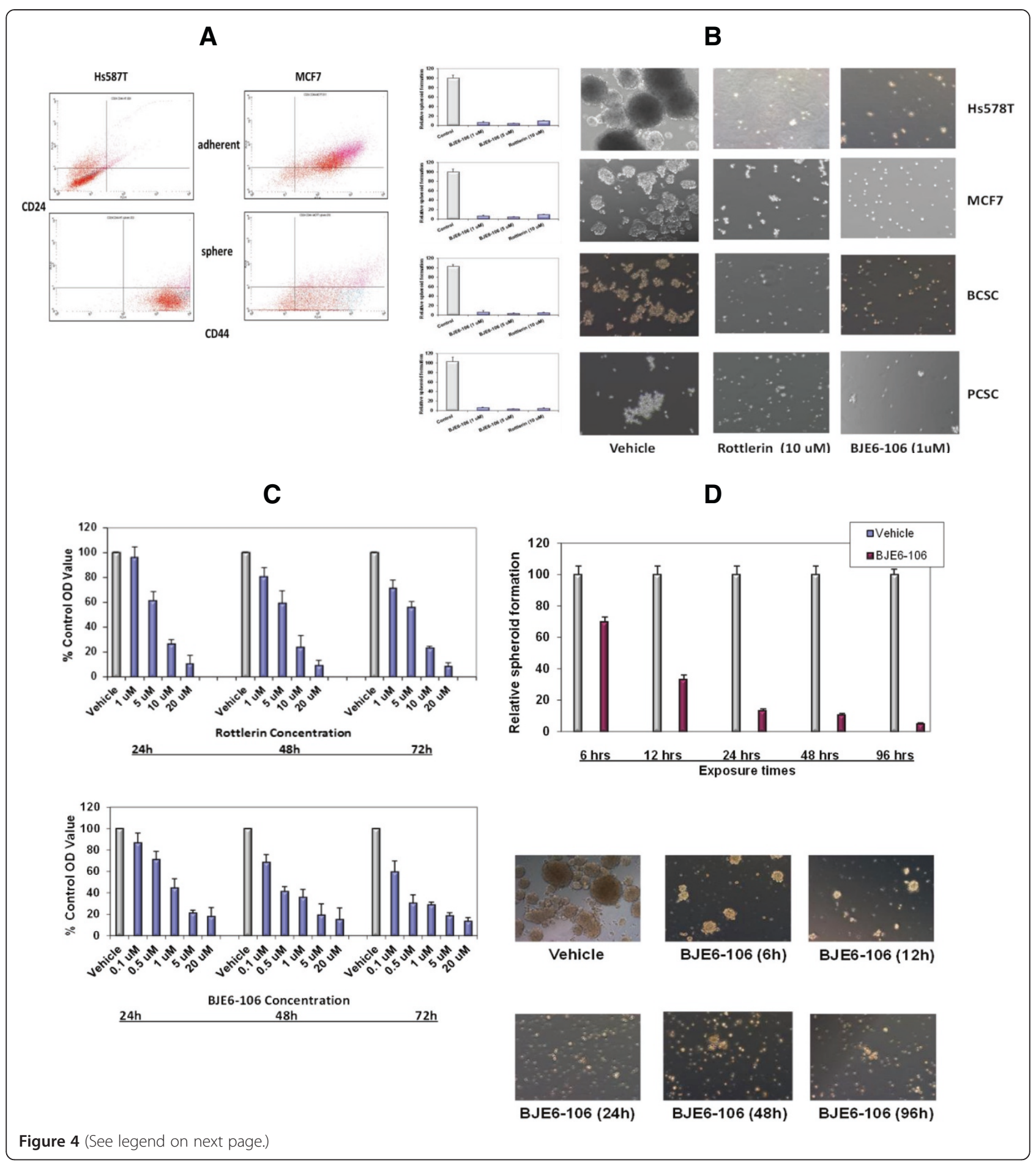


(See figure on previous page.)

Figure 4 Effects of PKC $\delta$ inhibitors on human tumor cell spheroid formation. (A) Hs578T and MCF7 were plated under adherent or non-adherent conditions. Tumor spheroids and adherent cells were collected at 96 hr, stained for CD24 and CD44, and analyzed by flow cytometry. (B) Hs578T, MCF7, breast cancer stem cells (BCSC) and pancreatic cancer stem cells (PCSC) were plated in tumor spheroid media, in the presence of rottlerin, BJE6-106, or DMSO (Control). Tumor spheroids were enumerated at $96 \mathrm{hr}$, and normalized to the number of spheroids in the control cultures (assigned an arbitrary value of 100\%). p values for comparison between vehicle and rottlerin or BJE6-106 effects were significant ( $\mathrm{p} \leq 0.001$ ). Photographs are of representative areas of the culture plates. (C) MCF7 cells were exposed BJE6-106 or to rottlerin at the indicated concentrations. The corresponding equivalent volume of solvent (DMSO) was used as a vehicle control (Vehicle). After 24, 48 and 72 hr of exposure, cell mass was evaluated by MTT assay. Control values were normalized to $100 \%$. p values for comparison between vehicle and rottlerin effects on cell number at 24 hr reached significance at $5 \mu \mathrm{M}$, and for BJE6-106 at $0.5 \mu \mathrm{M}$ ( $\mathrm{p} \leq 0.02)$, and were significant for all concentrations tested at 48 and 72 hr time points. (D) Hs578T cells were exposed to vehicle or BJE6-106 (1 $\mu \mathrm{M})$ for 6, 12, 24, 48 or 96 hr. Viable cells were enumerated and re-plated in media without BJE6-206, and spheroid numbers were quantitated 96 hr later. p values for comparison between vehicle and BJE6-106 effects on spheroid number were significant after $6 \mathrm{hr}$ of exposure ( $\mathrm{p} \leq 0.02)$, and remained significant at all time points thereafter. Error bars represent SEM.

to rottlerin or BJE6-106, concentrations in excess of $10 \mu \mathrm{M}$ and $1 \mu \mathrm{M}$, respectively, were required to repress growth by more than $80 \%$ (Figure $4 \mathrm{C}$ ). In contrast, growth of MCF7 spheroids was inhibited greater than $90 \%$ by rottlerin at $10 \mu \mathrm{M}$ and BJE6-106 at $1 \mu \mathrm{M}$. Washout studies using spheroid formation demonstrated that as little as $6 \mathrm{hr}$ of exposure to BJE6-106 at $1 \mu \mathrm{M}$ significantly repressed spheroid formation of Hs578T cells, with near maximum inhibition achieved by $24 \mathrm{hr}$ of exposure (Figure 4D).

In parallel studies, BJE6-106 at 0.5-1.0 $\mu \mathrm{M}$ and rottlerin at $10 \mu \mathrm{M}$ also efficiently inhibited the growth of tumor spheroids generated from two human melanoma cell lines (SBcl2, $>99.5 \%$ inhibition, $\mathrm{p}<0.001$; FN5, $>99.5 \%$ inhibition, $\mathrm{p}<0.001$ ), two human pancreatic cancer cell lines (MiaPaCa2, >97\% inhibition, $\mathrm{p}<0.001 ;$ Panc1, >99\% inhibition, $\mathrm{p}<0.001$ ); and two prostate cancer cell lines (DU145, >98\% inhibition, $\mathrm{p}<0.001$; PC3, >96\% inhibition, $\mathrm{p}<0.001)$.

A CSC-like phenotype can be induced during epithelial-mesenchymal transition (EMT) in transformed cell lines. Transformation of the "normal" human mammary epithelial cell line MCF $10 \mathrm{~A}$ and selection for a tumorigenic, metastatic phenotype in vivo produced the derivative line MCF 10C [53,54], which exhibits an EMT phenotype [60]. Cells of this malignant derivative also became ALDH + [61]. Transformation of these cells rendered them sensitive to rottlerin (Figure 5A) and to BJE6-106 (Figure 5B), compared to the parental MCF 10A line. The $\mathrm{IC}_{50}$ of rottlerin and BJE6-106 for the MCF 10C derivative was approximately $1 \mu \mathrm{M}$ and $0.1 \mu \mathrm{M}$, respectively, at $72 \mathrm{hr}$, whereas the $\mathrm{IC}_{50}$ for the parental MCF $10 \mathrm{~A}$ cells were $>20 \mu \mathrm{M}$.

The MCF $10 \mathrm{C}$ derivative also acquired the ability to efficiently form non-adherent spheroids (Figure 5C), in contrast to the parental MCF 10A cells. Growth of these spheroids was efficiently inhibited by exposure to rottlerin at $10 \mu \mathrm{M}$ or to BJE6-106 at $1 \mu \mathrm{M}$ (Figure 5D and E).

The relative lack of toxicity of PKC $\delta$ inhibition on the non-transformed, "normal" breast epithelial MCF 10A cells is noteworthy, and further supports the established non-essential role of this isozyme in normal cells and tissues. In other work, we have demonstrated that normal mouse embryo fibroblasts and human primary fibroblasts and epithelial cells and microvascular endothelial cells and primary melanocytes survive and proliferate in the setting of PKC $\delta$ knockdown or in concentrations of

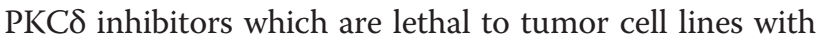
aberrant Ras signaling ([45-47,55]; Trojanowska et al., in preparation).

\section{Inhibition of PKC $\delta$ inhibits CSC tumor xenograft growth}

Another property of CSCs is their high tumorigenic potential. We therefore next sought to determine if PKC $\delta$ inhibition would inhibit the growth of CSCs in vivo. While the $3^{\text {rd }}$ generation PKC $\delta$ inhibitory compounds such as BJE6-106 are more potent and more cytotoxic to tumor cells and CSCs than previous generations, they have not been optimized for drug-like properties and are highly hydrophobic and poorly bioavailable, making efficient delivery of this generation of compounds in vivo unreliable. We therefore tested a prior-generation PKC $\delta$ inhibitor, rottlerin, which is readily bioavailable, in a tumor model. The human breast cancer stem cell (BCSC) cultures efficiently formed tumors as xenografts in nude mice. In comparison to vehicle control, rottlerin delivered intraperitoneally 5 days out of 7 effectively inhibited the growth of the xenografts, even producing tumor regression (Figure 6A). Survival was calculated on the day when tumor size reached the predetermined limit volume in the animals. The survival of the treated cohort extended long beyond the treatment interval, with some animals remaining tumor-free even at day 300 (Figure 6B).

We have previously demonstrated that depletion of $\mathrm{PKC} \delta$ is selectively toxic for cells with aberrant activation of Ras or Ras signaling pathways. Of the cell lines and CSC studied in this report, only a minority bore activating mutations of Ras itself (the pancreatic cancer cells are K-Ras mutant, and the melanoma cells are N-Ras mutant). MCF7 and the primary prostate and breast cancer stem cells, for example, had normal Ras 

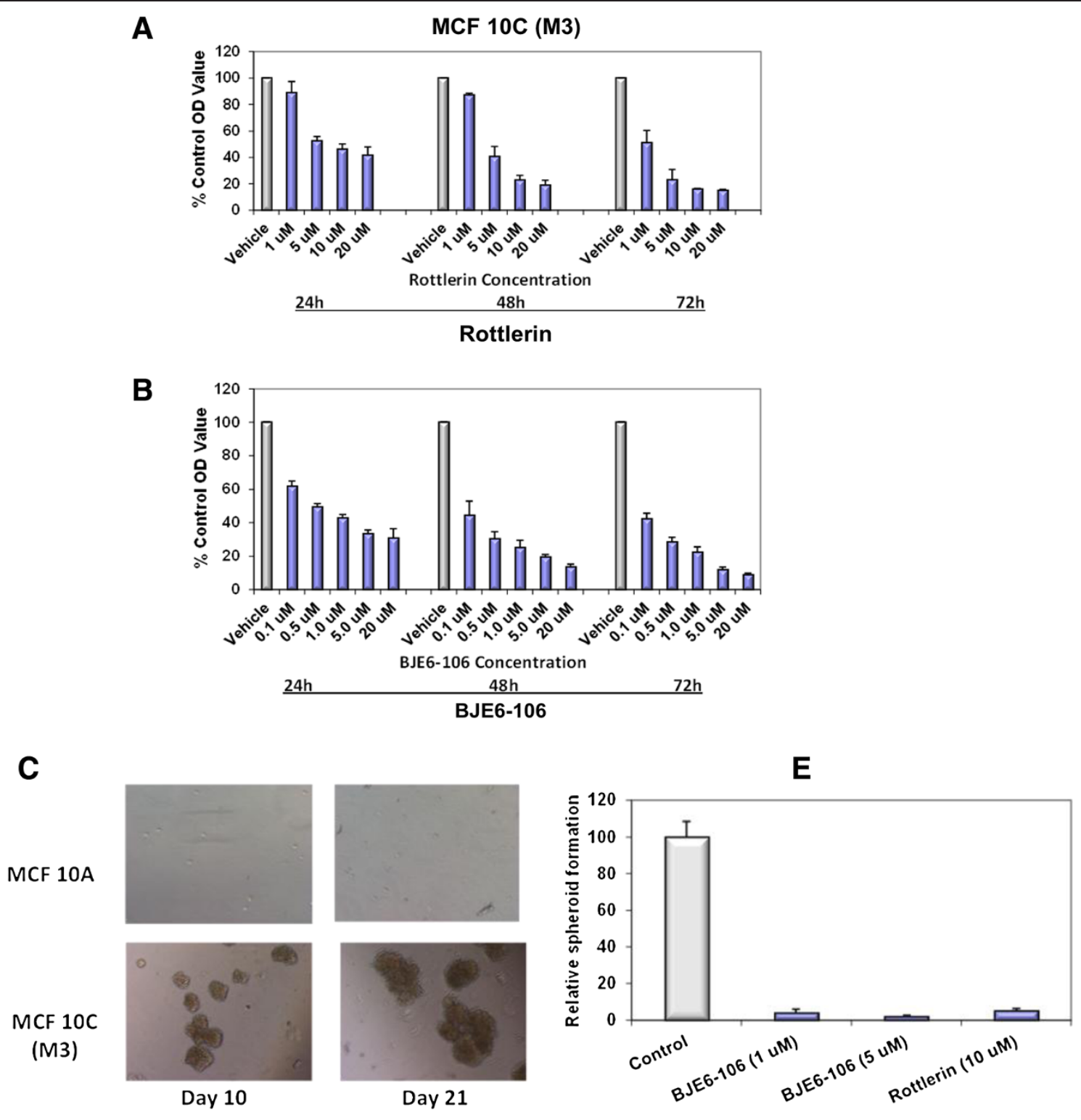

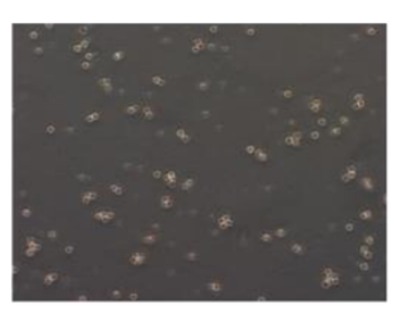

Day 1 (Cont)

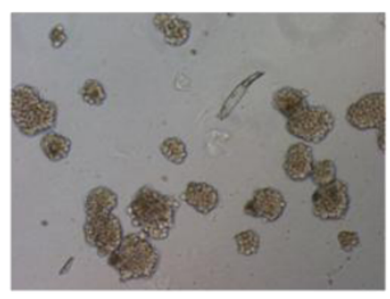

Day 10 (Cont)

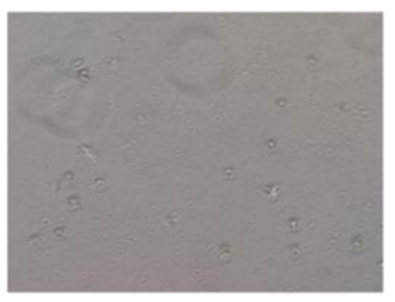

Day 10 (BJE6-106)

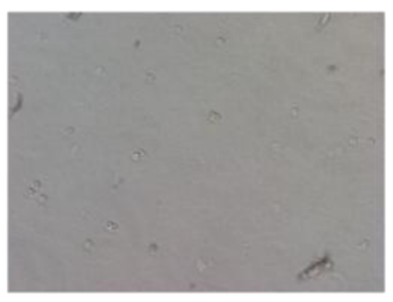

Day 10 (Rottlerin)

Figure $\mathbf{5}$ (See legend on next page.) 
(See figure on previous page.)

Figure 5 Effects of PKC $\delta$ inhibitors on growth and spheroid formation in non-transformed and transformed human breast epithelial cells. MCF 10A cells and cells from the derived tumorigenic line MCF 10C (also called M3), were grown to 80\% confluence in 96-well plates and then exposed to rottlerin at concentrations ranging from 1 to $20 \mu \mathrm{M}$ (A) or to BJE6-106 at concentrations ranging from 0.1 to $20 \mu \mathrm{M}$ (B). The corresponding equivalent volume of solvent (DMSO) was used as a vehicle control (Vehicle). After 24, 48 and 72 hr of exposure, cell mass was evaluated by MTT assay. Control (vehicle) values were normalized to 100\%. Error bars represent SEM. p values for comparison between vehicle and PKC $\delta$ inhibitors on MCF 10A cell number only reached significance $(p<0.05)$ at $48 \mathrm{hr}$ at $20 \mu \mathrm{M}$ for rottlerin, and at $1 \mu \mathrm{M}$ for BJE6-106. In contrast, significant effects of the inhibitors on the MCF $10 \mathrm{C}$ cells were observed as early as $24 \mathrm{hr}$ for rottlerin (at $5 \mu \mathrm{M}$ ) and for BJE6-106 (at $0.1 \mu \mathrm{M}$ ). (C) MCF 10A and MCF 10C cells were plated at 10,000 cells per well in tumor spheroid media, and spheroid formation was assessed at days 10 and 21. Representative photographs are shown. (D) MCF 10C cells were plated at 10,000 cells per well in tumor spheroid media, in the presence of rottlerin $(5 \mu \mathrm{M})$, or BJE6-106 (1 $\mu \mathrm{M}$ or $5 \mu \mathrm{M})$, or DMSO vehicle (Control). Tumor spheroids were enumerated at 10 days. Representative photographs are shown. (E) Spheroid numbers were normalized to the number of spheroids in the control cultures (assigned an arbitrary value of 100\%) and plotted. Error bars represent SEM. $p$ values for comparison between vehicle and rottlerin or BJE6-106 effects on spheroid number were significant $(p<0.001)$.

alleles. Analysis of Ras signaling pathways of cells derived from the CSCs, however, showed relative increases of pERK or pAKT, compared to the respective parental (adherent, non-spheroid) cells (Figure 7). These findings indicate relative activation of the MEK/ERK pathway in BCSC, MCF7 and Hs578T CSCs, and relative activation of the $\mathrm{PI}_{3} \mathrm{~K}-\mathrm{AKT}$ pathway in MDA231 CSCs.

\section{Discussion}

Small populations of cancer cells within multiple types of solid tumors have been identified based on cell surface marker expression and other phenotypic and functional characteristics. These subpopulations of tumor cells have often demonstrated a $>100$-fold increase in tumorigenic potential, compared to the remainder of the cells in the tumor. Furthermore, tumors that form from these cancer stem cells are indistinguishable from the human tumors in which they originate, indicating that the tumorinitiating cells are stem cell-like in their ability to selfrenew and give rise to a heterogeneous cell population. Much recent data suggests that elimination of these cancer stem cells, which are typically resistant to conventional

A
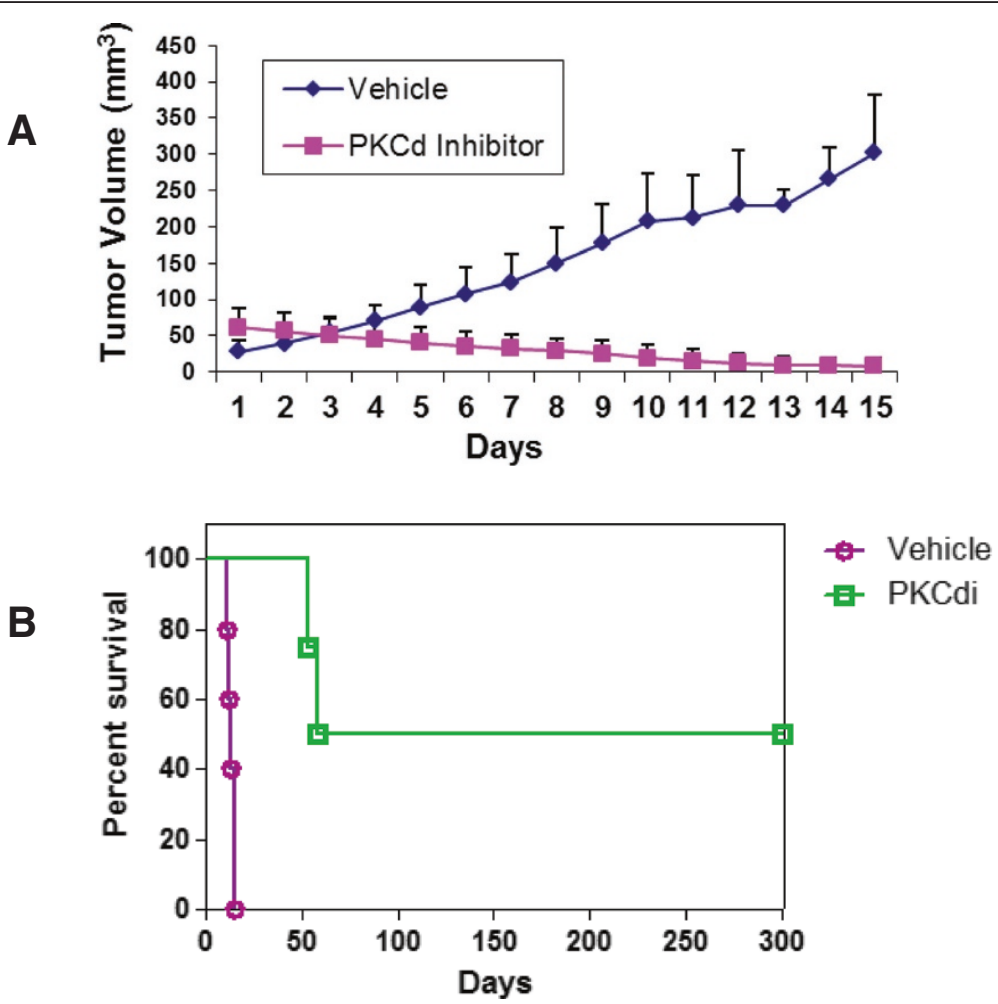

Figure 6 Effects of PKC $\delta$ inhibitor on tumor growth and survival in a xenograft human breast cancer stem cell model. Breast cancer stem cell xenografts were established and animals were treated with vehicle or rottlerin for 15 days, as described in Methods. (A) Tumor volumes plotted over time, until tumors in all the control animals reached the maximum volume allowed by the protocol (approximately 15 days). (B) Kaplan-Meier plot of survival of vehicle control or rottlerin (PKC $\mathrm{i}$ )-treated animals, with monitoring continuing after cessation of treatment at day 15 . 


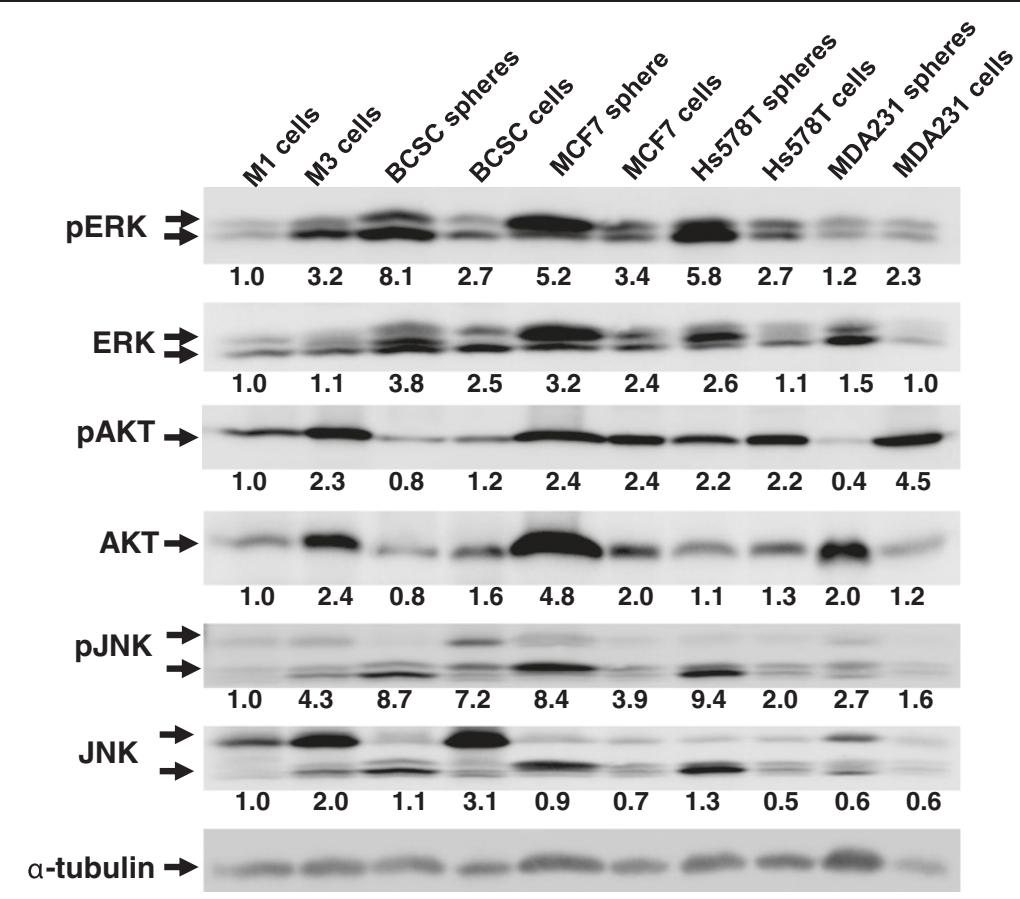

Figure 7 Immunoblot analysis of Ras-signaling pathways in tumor cells, cell lines, or spheres. Hs578T, MCF7, MDA231 and breast cancer stem cells (BCSC) were plated in tumor spheroid media under adherent or non-adherent conditions. Tumor spheroids and adherent cells were collected at $96 \mathrm{hr}$, and lysed. MCF 10A (M1) and MCF 10C (M3) lysates were also prepared. The lysates were separated by electrophoresis and immunoblotted with antibodies against ERK, pEKR, AKT, pAKT, JNK, pJNK. Immunoblotting of a-tubulin serves as a loading control. For quantitation, the digital intensity of the bands was first normalized to a-tubulin in each lane, and then expressed relative to the signal for the MCF 10A (M1) cell line. Values are shown under each band.

therapies, represents the most formidable barrier to $\mathrm{cu}$ ring solid tumors $[1,4,5,32,33,35]$. CSCs, or subclones thereof, are the most likely perpetrators of invasion and metastasis $[6,62]$.

Recent findings have shown the existence of activated and quiescent repertoires of stem cells in established tumor cell lines as well as primary tumor cell isolates, and their ability to interchange between these conditions [37]. Sphere-forming assays (SFA) are believed to evaluate the differentiation and self-renewal capabilities of a tumor cell population by assessing the potential of a tumor cell to behave like a stem cell, and are widely used in stem cell studies [37]. Sphere-forming assays have been commonly used to retrospectively identify normal and cancer stem cells, and measure stem cell/early progenitor activity in multiple types of solid cancers $[38,63,64]$. Increased expression of "stemness-related genes" [65] was observed when comparing solid tumor cell lines grown as 3D spheroids to monolayers.

Our identification of PKC $\delta$ as a critical mediator of survival in multiple types of solid tumors, including prostate, breast, lung, pancreatic, neuroendocrine and melanomas [45-48] raised the possibility that CSC populations might be similarly dependent upon the activity of this enzyme. The effects of PKC $\delta$ inhibition on CSCs, however, had not been previously explored.

We first validated PKC $\delta$ as a target in diverse CSCs by demonstrating here that specific and selective downregulation of PKC $\delta$ by shRNA was sufficient to prevent the growth of human breast, pancreatic and prostate cancer stem-like cell cultures, and to induce cytotoxicity.

Potential therapeutic translation of this synthetic lethal approach required the development of small molecule probes. As no PKC $\delta$-selective inhibitors had been developed to date, we initially used pharmacophore modeling and docking of rottlerin, a well-established but not highlyspecific inhibitor of $\mathrm{PKC} \delta$, into the crystal structure of $\mathrm{PKC} \theta$, to identify regions of the molecule important for PKC $\delta$-selectivity. The initial new molecule showing activity against PKC (KAM1) was formed by combining structural elements of the broad spectrum protein kinase inhibitor staurosporine and rottlerin. The chromene portion of rottlerin was combined with the carbazole portion of staurosporine to produce KAM1 [47]. KAM1 was further modified to develop 36 new analogs, including BJE6-106, which inhibits $\mathrm{PKC} \delta$ with an $\mathrm{IC}_{50}$ value of 50 $\mathrm{nM}$ and is approximately 1000 -fold selective versus PKC $\alpha$. Specificity for PKCס over "classical" PKC isoforms, like 
PKC $\alpha$, is important, as inhibition of $\mathrm{PKC} \alpha$ is generally toxic to all cells, normal and malignant, and would render these inhibitors non-"tumor-targeted". We have shown that B106 exerts potent cytotoxic activity against N-Ras-mutant human melanomas and B-Raf-mutant melanoma lines that have developed resistance to B-Raf inhibitors by aberrant activation of alternative Ras signaling pathways $[48,55]$.

We demonstrate here that first, second and third generation PKC $\delta$ inhibitors (exemplified by rottlerin, KAM1 and BJE6-106, respectively), inhibit the growth of human cancer stem-like cell cultures isolated from tumors, as well as CSC-like cells derived from cell lines by spheroid formation on non-adherent surfaces. Our prior studies would have predicted that the CSC isolates or spheroids derived from cell lines that contained activating mutations of N-Ras or K-Ras would likely be susceptible to

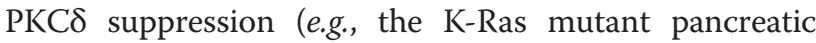
carcinomas and the N-Ras mutant melanomas). The reason for the susceptibility of the stem-like tumor cells containing wt-Ras alleles, however, was not immediately apparent. One reason for their susceptibility is likely to be upregulation of Ras effector pathways (MEK-ERK or $\mathrm{PI}_{3} \mathrm{~K} / \mathrm{AKT}$ signaling) in CSC spheres derived from cell lines, compared to the non-CSC parental cultures. We have reported previously that isolated activation of the MEK-ERK effector pathway or the $\mathrm{PI}_{3} \mathrm{~K} / \mathrm{AKT}$ effector pathway was sufficient to make cells dependent upon PKC $\delta$ for survival [45-47]. The finding of higher levels of Ras effector pathway activation in the CSC sphere subpopulation compared to the parental cells may also explain why in at least one instance (MCF7) the sphereforming CSC cells were substantially more susceptible to PKCS inhibition than non-CSC cells population. Interestingly, a recent report has identified a requirement for PKC $\delta$ in erbB2-driven proliferation of breast cancer cells [66], and erbB2 drives aberrant Ras pathway signaling. Furthermore, activation of MAPK pathways in basal-like breast cancers has been reported to promote a cancer stem cell-like phenotype [67], and activation of Ras/ MAPK signaling was reported to protect breast cancer stem cells from certain stem-cell targeted drugs [68]. Collectively, these reports, together with our findings, suggest that a PKC $\delta$-targeted approach to breast cancer stem cell populations, which exploits a synthetic lethal interaction with aberrant Ras signaling, may be particularly effective.

Inhibitory effects of PKC $\delta$ suppression on the IL6Stat3 axis, which is critical for CSC genesis or maintenance in a number of tumor cells types [69-71], may also contribute to the actions of PKC $\delta$ inhibition on CSC growth and survival, and will be reported separately.

Epithelial-to-mesenchymal transition (EMT), induced either by paracrine signaling from cancer-associated fibroblasts (CAFs) or neighboring tumor cells, has been associated with the acquisition of a stem cell phenotype [72]. In culture, when immortalized normal or transformed human mammary epithelial cells (HMECs) are stimulated to undergo an epithelial-to-mesenchymal transition (EMT), the transition confers stem-like cell properties upon normal or transformed epithelial cells in culture, partly because the cells acquire a CD44+/CD24 (low) phenotype, similar to breast cancer stem cells.

The idea that cancer cells might reversibly transition between epigenetically-defined tumorigenic and nontumorigenic states is of interest in part because mechanisms that generate reversible heterogeneity can confer resistance to therapies [73,74]. We took advantage of a previously-established cell line model system for breast cancer EMT, which consists of a parental spontaneouslyimmortalized mammary epithelial cell line, MCF 10A (M1), and one of its derivatives, MCF 10C (M3), derived from a xenograft in nude mice that progressed to carcinoma $[53,54]$. These cell lines were previously reported to exhibit distinct tumorigenic properties when re-implanted in nude mice; MCF 10A is non-tumorigenic, while MCF 10C forms low-grade, well-differentiated carcinomas $[53,54,60]$. Furthermore, MCF $10 \mathrm{C}$ has acquired phenotypic changes consistent with mesenchymal morphology and gene and protein expression patterns characteristic of EMT, including expression of mesenchymal markers (fibronectin, vimentin, and $\mathrm{N}$-cadherin) with concomitant downregulation of E-cadherin, $\beta$-catenin, and $\gamma$-catenin. MCF 10C also expresses high levels of Nanog, and Sox4, which are markers of cancer stem cells [61]. We found that the mesenchymal, CSC-like MCF 10C subline was much more sensitive to PKC $\delta$ inhibitors than the epithelial-like "normal" MCF 10A cells from which they were derived. Furthermore, the MCF 10C line acquired the capacity to efficiently form spheroids when grown in non-adherent conditions, and this tumor spheroid formation was inhibited by inhibition of PKC $\delta$ activity.

\section{Conclusions}

Collectively, these findings suggest that human cancer stem-like cells isolated from diverse sources and tumor types require PKC $\delta$ activity for their growth or maintenance in vitro and in vivo, making this isozyme a novel tumor-specific target. Taken together with the previous demonstration by our group and others of the cytotoxic effects of PKC $\delta$ inhibition on the non-CSC population of many tumor cell types, $\mathrm{PKC} \delta$ inhibitors hold the promise of eliminating both the majority non-CSC population and the latent and resistant CSC population comprising human tumors.

\section{Abbreviations}

BCSC: Primary human breast adenocarcinoma stem cells; CSC: Cancer stem-like cell; MAPK: MAP kinase; PCSC: Primary human pancreatic adenocarcinoma stem 
cells; PKC 8 : Protein kinase C delta; PKCa: Protein kinase C alpha; PrCSC: Primary human prostate adenocarcinoma stem cells; shRNA: Short hairpin RNA.

\section{Competing interests}

DVF and RMW have applied for a patent on certain of the PKC-delta inhibitory compounds described in this report. The other authors have no competing interests to disclose.

\section{Authors' contributions}

ZC and LWF carried out the molecular and biochemical studies, and participated in the preparation of the manuscript. RMW and DVF designed the novel inhibitory compounds. RMW synthesized the compounds and participated in the preparation of the manuscript. DVF conceived the study, and participated in its design and coordination and drafted the manuscript. All authors read and approved the final manuscript.

\section{Acknowledgements}

This study was supported by National Cancer Institute grants CA112102, CA164245, and CA141908, Department of Defense grants PC100093 and CA110396, the Melanoma Research Alliance, and a research award from the Scleroderma Foundation, the Karin Grunebaum Cancer Research Foundation (DVF): and the Colorado State University Cancer Super Cluster and Phoenicia Biosciences, Inc. (RMW).

\section{Author details}

${ }^{1}$ Cancer Center, Boston University School of Medicine, K-712C, 72 E. Concord St., Boston, MA 02118, USA. ²Department of Medicine, Boston University School of Medicine, K-712C, 72 E. Concord St., Boston, MA 02118, USA. ${ }^{3}$ Department of Chemistry, Colorado State University, 1301 Centre Ave, Fort Collins, CO 80523, USA. ${ }^{4}$ University of Colorado Cancer Center, Aurora, CO 80045, USA. ${ }^{5}$ Department of Pediatrics, Boston University School of Medicine, K-712C, 72 E. Concord St., Boston, MA 02118, USA. ${ }^{6}$ Department of Biochemistry, Boston University School of Medicine, K-712C, 72 E. Concord St., Boston, MA 02118, USA. ${ }^{7}$ Department of Microbiology, Boston University School of Medicine, K-712C, 72 E. Concord St., Boston, MA 02118, USA. ${ }^{8}$ Department of Pathology, Boston University School of Medicine, K-712C, 72 E. Concord St., Boston, MA 02118, USA. ${ }^{9}$ Department of Laboratory Medicine, Boston University School of Medicine, K-712C, 72 E. Concord St., Boston, MA 02118, USA.

Received: 28 October 2013 Accepted: 6 February 2014

Published: 14 February 2014

\section{References}

1. Reya T, Morrison SJ, Clarke MF, Weissman IL: Stem cells, cancer, and cancer stem cells. Nature 2001, 414:105-111.

2. Lapidot T, Sirard C, Vormoor J, Murdoch B, Hoang T, Caceres-Cortes J, et al: A cell initiating human acute myeloid leukaemia after transplantation into SCID mice. Nature 1994, 367:645-648.

3. Tirino V, Desiderio V, Paino F, De RA, Papaccio F, La NM, et al: Cancer stem cells in solid tumors: an overview and new approaches for their isolation and characterization. FASEB J 2012.

4. Clevers H: Stem cells, asymmetric division and cancer. Nat Genet 2005, 37:1027-1028

5. Trumpp A, Wiestler OD: Mechanisms of Disease: cancer stem cellstargeting the evil twin. Nat Clin Pract Oncol 2008, 5:337-347.

6. Baccelli I, Trumpp A: The evolving concept of cancer and metastasis stem cells. J Cell Biol 2012, 198:281-293.

7. Al-Hajj M, Wicha MS, Benito-Hernandez A, Morrison SJ, Clarke MF: Prospective identification of tumorigenic breast cancer cells. Proc Natl Acad Sci USA 2003, 100:3983-3988.

8. Singh SK, Clarke ID, Terasaki M, Bonn VE, Hawkins C, Squire J, et al: Identification of a cancer stem cell in human brain tumors. Cancer Res 2003, 63:5821-5828.

9. Bao S, Wu Q, McLendon RE, Hao Y, Shi Q, Hjelmeland AB, et al: Glioma stem cells promote radioresistance by preferential activation of the DNA damage response. Nature 2006, 444:756-760.

10. Piccirillo SG, Reynolds BA, Zanetti N, Lamorte G, Binda E, Broggi G, et al: Bone morphogenetic proteins inhibit the tumorigenic potential of human brain tumour-initiating cells. Nature 2006, 444:761-765.
11. Tirino V, Desiderio V, D'Aquino R, De FF, Pirozzi G, Graziano A, et al: Detection and characterization of CD133+ cancer stem cells in human solid tumours. PLOS One 2008, 3:e3469.

12. Tirino V, Desiderio V, Paino F, De RA, Papaccio F, Fazioli F, et al: Human primary bone sarcomas contain CD133+ cancer stem cells displaying high tumorigenicity in vivo. FASEB J 2011, 25:2022-2030.

13. Collins AT, Berry PA, Hyde C, Stower MJ, Maitland NJ: Prospective identification of tumorigenic prostate cancer stem cells. Cancer Res 2005, 65:10946-10951.

14. Bapat SA, Mali AM, Koppikar CB, Kurrey NK: Stem and progenitor-like cells contribute to the aggressive behavior of human epithelial ovarian cancer. Cancer Res 2005, 65:3025-3029.

15. Alvero AB, Chen R, Fu HH, Montagna M, Schwartz PE, Rutherford T, et al: Molecular phenotyping of human ovarian cancer stem cells unravels the mechanisms for repair and chemoresistance. Cell Cycle 2009, 8:158-166.

16. Curley MD, Therrien VA, Cummings $C L$, Sergent $P A$, Koulouris $C R$, Friel $A M$ et al: CD133 expression defines a tumor initiating cell population in primary human ovarian cancer. Stem Cells 2009, 27:2875-2883.

17. Stewart JM, Shaw PA, Gedye C, Bernardini MQ, Neel BG, Ailles LE: Phenotypic heterogeneity and instability of human ovarian tumorinitiating cells. Proc Natl Acad Sci U S A 2011, 108:6468-6473.

18. Zhang S, Balch C, Chan MW, Lai HC, Matei D, Schilder JM, et al: Identification and characterization of ovarian cancer-initiating cells from primary human tumors. Cancer Res 2008, 68:4311-4320.

19. Takaishi S, Okumura T, Tu S, Wang SS, Shibata W, Vigneshwaran R, et al: Identification of gastric cancer stem cells using the cell surface marker CD44. Stem Cells 2009, 27:1006-1020.

20. Eramo A, Lotti F, Sette G, Pilozzi E, Biffoni M, Di VA, et al: Identification and expansion of the tumorigenic lung cancer stem cell population. Cell Death Differ 2008, 15:504-514.

21. Tirino V, Camerlingo R, Franco R, Malanga D, La RA, Viglietto G, et al: The role of CD133 in the identification and characterisation of tumourinitiating cells in non-small-cell lung cancer. Eur J Cardiothorac Surg 2009, 36:446-453

22. Dalerba P, Dylla SJ, Park IK, Liu R, Wang X, Cho RW, et al: Phenotypic characterization of human colorectal cancer stem cells. Proc Natl Acad Sci USA 2007, 104:10158-10163.

23. O'Brien CA, Pollett A, Gallinger S, Dick JE: A human colon cancer cell capable of initiating tumour growth in immunodeficient mice. Nature 2007, 445:106-110.

24. Huang EH, Hynes MJ, Zhang T, Ginestier C, Dontu G, Appelman H, et al: Aldehyde dehydrogenase 1 is a marker for normal and malignant human colonic stem cells (SC) and tracks SC overpopulation during colon tumorigenesis. Cancer Res 2009, 69:3382-3389.

25. Ricci-Vitiani L, Lombardi DG, Pilozzi E, Biffoni M, Todaro M, Peschle C, et al: Identification and expansion of human colon-cancer-initiating cells. Nature 2007, 445:111-115.

26. Hermann PC, Huber SL, Herrler T, Aicher A, Ellwart JW, Guba M, et al: Distinct populations of cancer stem cells determine tumor growth and metastatic activity in human pancreatic cancer. Cell Stem Cell 2007, 1:313-323.

27. Li C, Heidt DG, Dalerba P, Burant CF, Zhang L, Adsay V, et al: Identification of pancreatic cancer stem cells. Cancer Res 2007, 67:1030-1037.

28. Schatton T, Murphy GF, Frank NY, Yamaura K, Waaga-Gasser AM, Gasser M, et al: Identification of cells initiating human melanomas. Nature 2008, 451:345-349.

29. Boiko AD, Razorenova OV, van de Rijn M, Swetter SM, Johnson DL, Ly DP, et al: Human melanoma-initiating cells express neural crest nerve growth factor receptor CD271. Nature 2010, 466:133-137.

30. Fang D, Nguyen TK, Leishear K, Finko R, Kulp AN, Hotz S, et al: A tumorigenic subpopulation with stem cell properties in melanomas. Cancer Res 2005, 65:9328-9337.

31. Prince ME, Sivanandan R, Kaczorowski A, Wolf GT, Kaplan MJ, Dalerba P, et al: Identification of a subpopulation of cells with cancer stem cell properties in head and neck squamous cell carcinoma. Proc Natl Acad Sci USA 2007, 104:973-978.

32. Li Y, Laterra J: Cancer stem cells: distinct entities or dynamically regulated phenotypes? Cancer Res 2012, 72:576-580.

33. Dick JE: Stem cell concepts renew cancer research. Blood 2008, 112:4793-4807. 
34. Clevers $\mathrm{H}$ : The cancer stem cell: premises, promises and challenges. Nat Med 2011, 17:313-319.

35. Nguyen LV, Vanner R, Dirks P, Eaves CJ: Cancer stem cells: an evolving concept. Nat Rev Cancer 2012, 12:133-143.

36. Franken NA, Rodermond HM, Stap J, Haveman J, Van BC: Clonogenic assay of cells in vitro. Nat Protoc 2006, 1:2315-2319.

37. Pastrana E, Silva-Vargas V, Doetsch F: Eyes wide open: a critical review of sphere-formation as an assay for stem cells. Cell Stem Cell 2011, 8:486-498.

38. Ponti D, Costa A, Zaffaroni N, Pratesi G, Petrangolini G, Coradini D, et al: Isolation and in vitro propagation of tumorigenic breast cancer cells with stem/progenitor cell properties. Cancer Res 2005, 65:5506-5511.

39. Han ME, Jeon TY, Hwang SH, Lee YS, Kim HJ, Shim HE, et al: Cancer spheres from gastric cancer patients provide an ideal model system for cancer stem cell research. Cell Mol Life Sci 2011, 68:3589-3605.

40. Dean M, Fojo T, Bates S: Tumour stem cells and drug resistance. Nat Rev Cancer 2005, 5:275-284.

41. Gomez-Casal R, Bhattacharya C, Ganesh N, Bailey L, Basse P, Gibson M, et al: Non-small cell lung cancer cells survived ionizing radiation treatment display cancer stem cell and epithelial-mesenchymal transition phenotypes. Mol Cancer 2013, 12:94.

42. Fabian A, Barok M, Vereb G, Szollosi J: Die hard: are cancer stem cells the Bruce Willises of tumor biology? Cytometry A 2009, 75:67-74

43. Valent P, Bonnet D, De MR, Lapidot T, Copland M, Melo JV, et al: Cancer stem cell definitions and terminology: the devil is in the details. Nat Rev Cancer 2012, 12:767-775.

44. Li X, Lewis MT, Huang J, Gutierrez C, Osborne CK, Wu MF, et al: Intrinsic resistance of tumorigenic breast cancer cells to chemotherapy. J Natl Cancer Inst 2008, 100:672-679.

45. Xia S, Forman LW, Faller DV: Protein Kinase C $\{$ delta\} is required for survival of cells expressing activated p21RAS. I Biol Chem 2007, 282:13199-13210.

46. Xia S, Chen Z, Forman LW, Faller DV: PKCdelta survival signaling in cells containing an activated p21Ras protein requires PDK1. Cell Signal 2009, 21:502-508

47. Chen Z, Forman LW, Miller KA, English B, Takashima A, Bohacek RA, et al: The proliferation and survival of human neuroendocrine tumors is dependent upon protein kinase C-delta. Endocr Relat Cancer 2011, 18:759-771.

48. Takashima A, Faller DV: Targeting the RAS oncogene. Expert Opin Ther Targets 2013.

49. Basu A, Pal D: Two faces of protein kinase Cdelta: the contrasting roles of PKCdelta in cell survival and cell death. ScientificWorldJournal 2010, 10:2272-2284

50. Leitges M, Mayr M, Braun U, Mayr U, Li C, Pfister G, et al: Exacerbated vein graft arteriosclerosis in protein kinase Cdelta-null mice. J Clin Invest 2001, 108:1505-1512.

51. Zhu T, Chen L, Du W, Tsuji T, Chen C: Synthetic Lethality Induced by Loss of PKC delta and Mutated Ras. Genes Cancer 2010, 1:142-151.

52. Symonds JM, Ohm AM, Carter CJ, Heasley LE, Boyle TA, Franklin WA, et al: Protein kinase $\mathrm{C}$ delta is a downstream effector of oncogenic K-ras in lung tumors. Cancer Res 2011, 71:2087-2097.

53. Strickland LB, Dawson PJ, Santner SJ, Miller FR: Progression of premalignant MCF10AT generates heterogeneous malignant variants with characteristic histologic types and immunohistochemical markers. Breast Cancer Res Treat 2000, 64:235-240.

54. Santner SJ, Dawson PJ, Tait L, Soule HD, Eliason J, Mohamed AN, et al: Malignant MCF10CA1 cell lines derived from premalignant human breast epithelial MCF10AT cells. Breast Cancer Res Treat 2001, 65:101-110

55. Takashima A, English B, Chen Z, Cao J, Cui R, Williams RM, et al: Protein Kinase $C$ delta is a therapeutic target in malignant melanoma with NRAS mutation. ACS Chem Biol. in press.

56. Guda K, Natale L, Markowitz SD: An improved method for staining cell colonies in clonogenic assays. Cytotechnology 2007, 54:85-88.

57. Gschwendt M, Muller HJ, Kielbassa K, Zang R, Kittstein W, Rincke G, et al: Rottlerin, a novel protein kinase inhibitor. Biochem Biophys Res Commun 1994, 199:93-98.

58. Susarla BT, Robinson MB: Rottlerin, an inhibitor of protein kinase Cdelta (PKCdelta), inhibits astrocytic glutamate transport activity and reduces GLAST immunoreactivity by a mechanism that appears to be PKCdeltaindependent. J Neurochem 2003, 86:635-645.
59. Davies SP, Reddy H, Caivano M, Cohen P: Specificity and mechanism of action of some commonly used protein kinase inhibitors. Biochem J 2000, 351:95-105

60. Pan H, Gao F, Papageorgis P, Abdolmaleky HM, Faller DV, Thiagalingam S: Aberrant activation of gamma-catenin promotes genomic instability and oncogenic effects during tumor progression. Cancer Biol Ther 2007, 6:1638-1643.

61. Papageorgis P, Lambert AW, Ozturk S, Gao F, Pan H, Manne U, et al: Smad signaling is required to maintain epigenetic silencing during breast cancer progression. Cancer Res 2010, 70:968-978.

62. Chaffer $\mathrm{CL}$, Weinberg RA: A perspective on cancer cell metastasis. Science 2011, 331:1559-1564.

63. Wang L, Mezencev R, Bowen NJ, Matyunina LV, McDonald JF: Isolation and characterization of stem-like cells from a human ovarian cancer cell line. Mol Cell Biochem 2012, 363:257-268.

64. Dontu G, Al-Hajj M, Abdallah WM, Clarke MF, Wicha MS: Stem cells in normal breast development and breast cancer. Cell Prolif 2003, 36(Suppl 1):59-72.

65. Busse A, Letsch A, Fusi A, Nonnenmacher A, Stather D, Ochsenreither S, et al: Characterization of small spheres derived from various solid tumor cell lines: are they suitable targets for T cells? Clin Exp Metastasis 2013, 30:781-789.

66. Allen-Petersen BL, Carter CJ, Ohm AM, Reyland ME: Protein kinase Cdelta is required for ErbB2-driven mammary gland tumorigenesis and negatively correlates with prognosis in human breast cancer. Oncogene 2013, 10:32-1.

67. Balko JM, Schwarz LJ, Bhola NE, Kurupi R, Owens P, Miller TW, et al: Activation of MAPK pathways due to DUSP4 loss promotes cancer stem cell-like phenotypes in basal-like breast cancer. Cancer Res 2013, 73:6346-6358.

68. Bhat-Nakshatri P, Goswami CP, Badve S, Sledge GW Jr, Nakshatri H: Identification of FDA-approved Drugs Targeting Breast Cancer Stem Cells Along With Biomarkers of Sensitivity. Sci Rep 2013, 3:2530.

69. Iliopoulos D, Hirsch HA, Wang G, Struhl K: Inducible formation of breast cancer stem cells and their dynamic equilibrium with non-stem cancer cells via IL6 secretion. Proc Natl Acad Sci U S A 2011, 108:1397-1402.

70. Wang H, Lathia JD, Wu Q, Wang J, Li Z, Heddleston JM, et al: Targeting interleukin 6 signaling suppresses glioma stem cell survival and tumor growth. Stem Cells 2009, 27:2393-2404.

71. Lin L, Liu A, Peng Z, Lin HJ, Li PK, Li C, et al: STAT3 is necessary for proliferation and survival in colon cancer-initiating cells. Cancer Res 2011, 71:7226-7237.

72. Alison MR, Lin WR, Lim SM, Nicholson LJ: Cancer stem cells: in the line of fire. Cancer Treat Rev 2012, 38:589-598.

73. Roesch A, Fukunaga-Kalabis M, Schmidt EC, Zabierowski SE, Brafford PA, Vultur A, et al: A temporarily distinct subpopulation of slow-cycling melanoma cells is required for continuous tumor growth. Cell 2010, 141:583-594.

74. Sharma SV, Lee DY, Li B, Quinlan MP, Takahashi F, Maheswaran S, et al: A chromatin-mediated reversible drug-tolerant state in cancer cell subpopulations. Cell 2010, 141:69-80.

\section{doi:10.1186/1471-2407-14-90}

Cite this article as: Chen et al:: Protein kinase C-delta inactivation inhibits the proliferation and survival of cancer stem cells in culture and in vivo. BMC Cancer 2014 14:90. 